\title{
Alterations in Some Biochemical Responses of Freshwater Mussels in Acute Imidacloprid Exposure
}

\author{
Ertan YOLOĞLU* \\ Adiyaman University, Faculty of Education, Department of Mathematics and Science Education, \\ Adlyaman, Turkey \\ ertanyologlu82@gmail.com,ORCID:0000-0002-9730-9471
}

\begin{abstract}
Imidacloprid is a widely used systemic neonicotinoid insecticide. The aim of this study is to identify potential harmful effects of imidacloprid in freshwater mussels (Unio mancus) which were exposed to sub-lethal concentrations $(1,10,100$, and $1000 \mu \mathrm{g}$ AI L1) for $96 \mathrm{~h}$. For this aim, glutathione s-transferase (GST) activity, carboxylesterase (CaE) activity, acetylcholinesterase (AChE) activity, glutathione reductase (GR) activity, reduced glutathione (GSH) level, and malondialdehyde (MDA) level were evaluated as biochemical markers of exposure in the gills and digestive glands. The actual imidacloprid concentrations in the test waters were determined by LC-MS/MS analysis. The results showed that the $\mathrm{AChE}$, GR, and $\mathrm{CaE}$ activities in the digestive glands significantly decreased at different exposure concentrations, while the MDA level significantly increased at the highest exposure concentration $(p<0.05)$. Considering the results in the gills, the lowest exposure concentration caused inhibition in AChE activity, while the highest exposure concentration caused significant induction in GST activity, GSH level and MDA level $(p<0.05)$. In addition, the measured imidacloprid concentrations were determined to be about $80 \%$ of the nominal imidacloprid concentrations. The data obtained from this study indicated that acute imidacloprid exposure caused biochemical alterations related to oxidative stress in mussels.
\end{abstract}

Keywords: Imidacloprid, Oxidative stress, Freshwater mussel, Neurotoxicity, LC$\mathrm{MS} / \mathrm{MS}$

\footnotetext{
* Corresponding Author
} 


\section{Akut İmidakloprid Maruziyetinde Tatlı Su Midyelerinin Bazı Biyokimyasal Yanıtlarındaki Değișimler}

\section{$\ddot{O} z$}

İmidakloprid yaygın olarak kullanılan bir sistemik neonikotinoid insektisittir. Bu çalışmanın amacı 96 saat süre ile imidaklopridin öldürücü olmayan konsantrasyonlarına

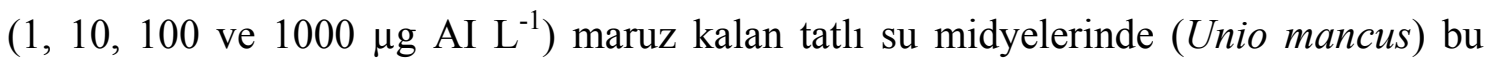
insektisitin potansiyel zararlı etkilerini belirlemektir. Bu amaçla, tatlı su midyelerinin solungaçlarında ve sindirim bezlerinde biyokimyasal belirteçler olarak glutatyon stransferaz (GST) aktivitesi, karboksilesteraz (CaE) aktivitesi, asetilkolinesteraz (AChE) aktivitesi, glutatyon redüktaz (GR) aktivitesi, redükte glutatyon (GSH) seviyesi ve malondialdehit (MDA) seviyesi değerlendirilmiştir. Test sularındaki gerçek imidakloprid konsantrasyonları LC-MS/MS analizi ile belirlenmiştir. Sonuçlar, sindirim bezlerindeki AChE, GR ve CaE aktivitelerinin farklı maruziyet konsantrasyonlarında anlamlı olarak azaldığını, MDA seviyesinin en yüksek maruziyet konsantrasyonunda anlamlı şekilde arttığını göstermiştir $(p<0.05)$. Solungaçlardaki sonuçlar göz önüne alındığında, en düşük maruziyet konsantrasyonu AChE aktivitesinde inhibisyona neden olurken, en yüksek maruziyet konsantrasyonu GST aktivitesinde, GSH seviyesinde ve MDA seviyesinde önemli indüksiyona neden olmuştur $(p<0.05)$. Ayrıca, ölçülen imidakloprid konsantrasyonlarının nominal imidakloprid konsantrasyonlarının yaklaşı 1 \%80'i düzeyinde olduğu belirlenmiştir. Bu çalışmadan elde edilen veriler, akut imidakloprid maruziyetinin midyelerde oksidatif stres ile ilgili biyokimyasal değişikliklere neden olduğunu göstermiştir.

Anahtar Kelimeler: İmidakloprid, Oksidatif stres, Tatlı su midyesi, Nörotoksisite, LC-MS/MS

\section{Introduction}

Agrochemicals such as pesticides cause various toxic effects on exposed organisms, therefore it is important to understand the mechanisms of these effects [1]. Pesticides, which can be found in different compartments of aquatic ecosystems, can cause negative effects in the short and long-term because they can accumulate in the upper trophic levels through the food chain according to their chemical properties [2]. The use of 
neonicotinoid insecticides, an important class of pesticides, has increased in recent years due to its various properties such as having a large spectrum of insects, being effective even at low doses, having high water solubility and low toxicity to mammals. Imidacloprid is the oldest and most widely used neonicotinoid insecticide in the world. The widespread use of imidacloprid in both agricultural and urban activities increases the risk of this insecticide being transported to aquatic ecosystems through different routes, such as erosion, surface flow and atmospheric decomposition [3]. Neonicotinoids are highly selective neurotoxins because they act as an agonist of the nicotinic acetylcholine receptor (nAChR) in post-synaptic membrane. Since these insecticides act more systemically, they do not only affect the central nervous system but also cause intracellular alterations in both vertebrates and invertebrates [4, 5]. Imidacloprid causes more serious adverse effects on non-target organisms than other neonicotinoid pesticides and is one of the most important potential risks for local freshwater ecosystems in particular [6].

Mussels that filter large amounts of water for vital activities have important ecological roles, such as organic matter recycling, phytoplankton level control and water turbidity regulation [2]. They are considered to be important biomonitor organisms of aquatic contamination due to their various characteristics, such as being sensitive to environmental changes, the sessile lifestyle, accumulation of pollutants in various tissues and widespread presence in different aquatic ecosystems. In addition, organisms fed by filtration like mussels may be exposed to pollutants either directly or by feeding [7].

Aquatic organisms that are exposed to xenobiotics such as pesticides have developed some biochemical defense mechanisms. Biochemical markers are important tools in understanding the mechanisms of action in various aquatic organisms [8]. In the present study, pesticide toxicity was evaluated using six selected biochemical markers. Acetylcholinesterase (AChE) activity is a widely used biochemical marker in the detection of neuroactive pesticide toxicity in aquatic organisms. Carboxylesterase $(\mathrm{CaE})$ is a phase I enzyme that plays a significant role in the hydrolysis and detoxification of many chemicals [9]. Glutathione S-transferase (GST) and glutathione reductase (GR) are enzymatic biochemical markers which are widely used in the evaluation of oxidative stress $[10,11]$. Reduced glutathione $(\mathrm{GSH})$ is non-enzymatic antioxidant that protects 
organisms against oxidative stress [12]. Malondialdehyde (MDA), a product of lipid peroxidation, is often used as an indicator of oxidative stress [13].

There are numerous studies in the literature about the toxicity of imidacloprid. However, although the commercial form of this insecticide is used more widely in various activities, there are a limited number of studies evaluating the effects of its commercial form on non-target organisms such as mussels. Furthermore, assessing the effects of its commercial form is a more realistic approach for environmental risk assessment studies. In this context, the main objective of this study is to evaluate the responses of selected biochemical markers related to oxidative stress and detoxification mechanisms in the digestive glands and gills of mussels exposed to commercial form of imidacloprid.

\section{Materials and Methods}

\subsection{Chemical}

The commercial form of imidacloprid (Confidor ${ }^{\circledR}$ SC 350, Bayer, Germany) that was purchased from a local agrochemical store was used in toxicity tests. The active ingredient (AI) of this commercial form was labeled as $350 \mathrm{~g} \mathrm{~L}^{-1}$.

Bradford reagent, bovine serum albumin (BSA), malondialdehyde bis (diethyl acetal) (MDA), thiobarbituric acid (TBA), trichloroacetic acid (TCA), 5,5'-dithio-bis(2nitrobenzoic acid) (DTNB), 1-chloro-2,4-dinitrobenzene (CDNB), p-nitrophenyl acetate (PNPA), acetylthiocholineiodide (ACTI), and reduced glutathione (GSH) were provided from Sigma (MO, USA). NADPH was purchased from MP Biomedicals (USA).

\subsection{Animals and Toxicity Test}

Specimens of Unio mancus were collected from the Atatürk Dam Lake in February 2019. Collected mussels were quickly transferred to the laboratory under suitable conditions with plastic containers filled with dam lake water. Before starting the experiments, the mussels were acclimated to the laboratory for two weeks in a $50 \mathrm{~L}$ polycarbonate tank filled with bottled water. The tank was continuously aerated with an air pump and the mussels were maintained in $14 / 10 \mathrm{~h} \mathrm{light} /$ dark cycle and at $20 \pm 1{ }^{\circ} \mathrm{C}$. They fed ad libitum every three days with commercially concentrated phytoplankton for aquatic invertebrates (Roti-Rich ${ }^{\mathrm{TM}}$ ). 
After acclimation, mussels were divided into five groups as a control and four exposure groups. Four mussels were placed in continuously aerated polycarbonate tanks filled with four liters of test water. All test groups were set in three replicates and twelve animals were used in each group (four animals in each replicate). Mussels were not fed during the experiment. The temperature, dissolved oxygen, $\mathrm{pH}$ and conductivity of the water samples of control and exposure groups were measured using a multiparameter device (YSI Pro Plus Multi-Parameter) at the beginning of the experiments (hour zero). The mean values of $\mathrm{pH}$, conductivity, temperature, and dissolved oxygen were determined as 7.58 (7.41-7.8), $22.32 \mu \mathrm{S} \mathrm{cm} \mathrm{cm}^{-1}$ (20.96-25.64), $15.5{ }^{\circ} \mathrm{C}$ (15.3-15.7), and $6.72 \mathrm{mg} \mathrm{L}^{-1}$ (6.62-6.84), respectively. Mussels were exposed to four nominal sub-lethal concentrations of imidacloprid $\left(1,10,100\right.$, and $\left.1000 \mu \mathrm{g} \mathrm{AI} \mathrm{L}^{-1}\right)$ in the $96 \mathrm{~h}$ static renewal test system. USEPA has determined the acute and chronic toxicity concentrations of imidacloprid for freshwater invertebrates as $0.385 \mu \mathrm{g} \mathrm{L}^{-1}$ and $0.01 \mu \mathrm{g} \mathrm{L}^{-1}$, respectively [14]. The lowest test concentration was selected based on these values determined by USEPA and the other concentrations increased geometrically by 10 -fold. At the end of the exposure period, gills and digestive glands of mussels were dissected on ice and stored in the plastic zipper bags at $-80{ }^{\circ} \mathrm{C}$ until biochemical experiments.

\subsection{LC-MS/MS Analysis of Imidacloprid in the Test Water}

The actual imidacloprid concentrations in the test waters were determined using a liquid chromatography tandem mass spectrometry (LC-MS/MS, Shimadzu Quadropole 8040) in Adiyaman University Central Research Laboratory. The conditions and gradient mode of LC-MS/MS were depicted in Table 1 and Table 2, respectively. The retention time of imidacloprid was approximately $4 \mathrm{~min}$. The calibration curve constructed from the standards for the calculation of imidacloprid concentrations was in the range of 1-100 $\mu \mathrm{g} \mathrm{L}^{-1}$. The limits of detection, quantification, and coefficient of determination $\left(\mathrm{r}^{2}\right)$ were determined as $0.12 \mu \mathrm{g} \mathrm{L}^{-1}, 0.37 \mu \mathrm{g} \mathrm{L}^{-1}$, and 0.998 , respectively. Imidacloprid was detected through the transitions $256.10 \rightarrow 208.80$ mass-to-charge ratios $(\mathrm{m} / \mathrm{z})$ and $256.20 \rightarrow 175.20$ $m / z$. The imidacloprid standard was purchased from Dr. Ehrenstorfer $\mathrm{GmbH}$ with $99.8 \%$ purity. Each water sample was analyzed in triplicate. 
Table 1. LC-MS/MS conditions

\begin{tabular}{ll}
\hline Mobil phase A & $1 \mathrm{mM}$ ammonium formate in $100 \%$ water \\
Mobil phase B & $100 \%$ methanol \\
Column & Inertsil ODS-4 $(2.1 \mathrm{~mm}$ I.D. $\times 50 \mathrm{~mm} \mathrm{~L} ., 3 \mu \mathrm{m})$ \\
Column oven temperature & $40{ }^{\circ} \mathrm{C}$ \\
Flow rate & $0.4 \mathrm{~mL} \mathrm{~min}{ }^{-1}$ \\
Interface voltage & $4.5 \mathrm{kV}$ \\
Nebulizing gas flow rate & $3 \mathrm{~L} \mathrm{~min}^{-1}$ \\
Drying gas flow rate & $15 \mathrm{~L} \mathrm{~min}^{-1}$ \\
DL temperature & $250{ }^{\circ} \mathrm{C}$ \\
Heat Block temperature & $450{ }^{\circ} \mathrm{C}$ \\
\hline
\end{tabular}

Table 2. Gradient mode of LC-MS/MS

\begin{tabular}{lcccc}
\hline Step & Time & Module & Command & Value \\
\hline 1 & 1.00 & Pumps & Pump B Conc. & 10 \\
2 & 5.00 & Pumps & Pump B Conc. & 95 \\
3 & 7.00 & Pumps & Pump B Conc. & 95 \\
4 & 7.01 & Pumps & Pump B Conc. & 10 \\
5 & 10.00 & Pumps & Pump B Conc. & 10 \\
6 & 10.01 & Controller & Stop & - \\
\hline
\end{tabular}

\subsection{Biochemical Assays}

The tissues were weighed and homogenized in 1:4 (w/v) ratio of $0.1 \mathrm{M} \mathrm{K}$ phosphate buffer ( $\mathrm{pH}$ 7.4) containing $0.15 \mathrm{M} \mathrm{KCl}, 1 \mathrm{mM}$ EDTA, $1 \mathrm{mM}$ DTT) using a Teflon-glass homogenizer (Heidolph RZR 2021). Five hundred microliters of homogenates were separated for MDA analysis. The remaining homogenates were centrifuged at $16000 \mathrm{x} \mathrm{g}$ for $20 \mathrm{~min}$ at $4{ }^{\circ} \mathrm{C}$ (Hettich $460 \mathrm{R}$ ) and then, the supernatants (S16) were transferred to eppendorf tubes for GST, GR, CaE, AChE and GSH measurements. The total protein level was measured according to Bradford [15]. The protein levels of the samples were determined using the standard curve constructed from measurements of the following BSA standard solutions. All biochemical measurements were performed using a microplate reader spectrophotometer (Thermo, Varioscan Flash 2000). Assays were run at $25^{\circ} \mathrm{C}$ in triplicate. All enzyme activities were expressed as specific activity (nmol/min/mg protein).

The GSH level was determined according to Jollow et al. [16], with some modifications adapted to microplate reader system. The absorbance was read at $412 \mathrm{~nm}$ against the GSH standard curve. The GSH level of samples was expressed as nmol GSH $\mathrm{mg}^{-1}$ protein. 
The MDA concentration was measured based on TBA reactive substance assay as described by Ohkawa et al., [17] with some modifications. The absorbance was read at $532 \mathrm{~nm}$. MDA contents were determined using malondialdehyde bis (diethyl acetal) as a standard. The MDA concentration was expressed as nmol MDA mg ${ }^{-1}$ protein.

The GST activity was determined by a spectrophotometric method according to protocol described by Habig et al., [18] using CDNB as substrate. The change in absorbance was measured at $344 \mathrm{~nm}$ for $2 \mathrm{~min}$.

The $\mathrm{CaE}$ activity was determined according to a modified procedure of Santhoshkumar and Shivanandappa for a microplate reader [19]. The reaction was initiated by the addition of PNPA as substrate to the reaction solution. The liberated pnitrophenol was monitored at $405 \mathrm{~nm}$ for $2 \mathrm{~min}$.

The AChE activity was determined according to a modified procedure of the Elman et al., method using ACTI as a substrate [20]. The change in absorbance was monitored at $412 \mathrm{~nm}$ for $3 \mathrm{~min}$.

The GR activity was determined according to Cribb et al., by microplate assay with modifications [21]. The reaction was initiated by the addition of GSSG into the reaction solution. The decrease in the amount of DTNB was monitored at $405 \mathrm{~nm}$ for $3 \mathrm{~min}$.

\subsection{Data Analysis}

All data were presented as mean values \pm standard errors calculated on twelve replicates. Shapiro-Wilk and Levene's tests were used to test normality and homogeneity of variance, respectively. Significant differences between the control and exposure groups were tested with one-way variance analysis (ANOVA) followed by Bonferroni post hoc test. Significant level was set at $p<0.05$ for all analysis. All statistical analyses conducted with the software package SPSS 22 (USA).

\section{Results and Discussion}

Neonicotinoids are potential surface water pollutants because they are less absorbable in the soil and have a higher solubility in water [4]. Imidacloprid-based neonicotinoids represent the greatest potential risk for non-target organisms living in local 
aquatic ecosystems such as dam lakes and rivers. Filter-feeding aquatic organisms may be exposed to these pesticides directly due to their contaminated environment or exposed by consuming contaminated microorganisms which are important nutrient sources [2]. Since most of the pesticides used today can be rapidly degraded under environmental conditions, they show their effects in a short-term. Therefore, it is important to determine the short-term effects of pesticides on organisms [22]. Also, changes in biochemical markers reflect the response of organisms and are considered as an early warning mechanism [23].

\subsection{Measured Concentrations of Imidacloprid in Test Waters}

The measured imidacloprid concentrations in the test waters obtained from LCMS/MS analysis was depicted in Table 3. The measured concentrations were determined to be approximately $20 \%$ lower than the calculated nominal concentrations. This difference between nominal and measured concentrations may be related to various factors such as photolytic degradation of the active ingredient, the use of liquid formulations, and the effect of $\mathrm{pH}$ [3]. Furthermore, the interference of imidacloprid with other compounds such as surfactant, solvent, and preservative in the content of commercial formulations is one of the possible reasons for the difference between the nominal concentrations and the measured concentrations [22].

Table 3. Imidacloprid concentrations measured by LC-MS/MS in test waters $(n=3)$

\begin{tabular}{cccc}
\hline $\begin{array}{c}\text { Nominal Concentrations } \\
(\boldsymbol{\mu g} \text { AI L-1) }\end{array}$ & \multicolumn{3}{c}{$\begin{array}{c}\text { Measured Concentrations } \\
\left(\boldsymbol{\mu g} \mathbf{L}^{-1} \pm \mathbf{S E}\right)\end{array}$} \\
\hline 0 & 0 & \pm & 0 \\
1 & 0.87 & \pm & 0.006 \\
10 & 7.48 & \pm & 0.141 \\
100 & 78.33 & \pm & 0.258 \\
1000 & 794.20 & \pm & 17.892 \\
\hline
\end{tabular}

\subsection{Biochemical Responses}

The alterations in selected biochemical markers after $96 \mathrm{~h}$ imidacloprid exposure were presented in Table 4. Significant alterations were observed in all biochemical markers in both tissues of mussels exposed to sub-lethal concentrations of imidacloprid. Although similar tendencies were observed in biochemical responses in both tissues, tissue-specific differences in the significance levels of these responses were determined. 
The digestive gland is one of the important organs for pesticide detoxification. On the other hand, the gill, which acts in the excretion of catabolic products, is one of the first routes for the intake of pollutants as it is in direct contact with water [1]. The tissuespecific differences in biochemical responses may be due to these functional characteristics of the digestive gland and gill.

Imidacloprid exposure caused inhibition of the AChE enzyme activity in both tissues. However, these inhibitions are not dose related. The lowest AChE activity was determined in $1 \mu \mathrm{g} \mathrm{AI} \mathrm{L}{ }^{-1}$ in the gill $(p<0.05)$ and $100 \mu \mathrm{g} \mathrm{AI} \mathrm{L}{ }^{-1}$ in the digestive gland $(p<0.05)$. According to the control group, the inhibition rate in these exposure groups was approximately $25 \%$ for both tissues (Fig. 1). Interestingly, it was observed that AChE activity in both tissues showed a U-shaped dynamic from low to a high concentration. Neonicotinoids target nAChRs and cause death of the neuron by generating continuous electrical impulses. Before death, AChE hydrolyzes acetylcholine to the coline and acetate so that it can terminate the electrical signals generated by nAChR. Because of these alterations in AChE activity, the effects of neonicotinoids on nAChR may occur indirectly [24]. Similarly, Dondero et al., reported that AChE activity was significantly reduced in the gill tissues of imidacloprid-exposed mussels at low concentrations [25]. In addition, various changes in AChE activity have been reported in aquatic organisms such as Daphnia magna and Chironomus riparius exposed to different concentrations of imidacloprid [26, 27]. By considering the results of the studies mentioned above, it can be assumed that AChE activity shows a species-specific dynamic.

In mussels exposed to imidacloprid, no significant changes in gill $\mathrm{CaE}$ activity were observed, although significant inhibitions were observed in the digestive gland $\mathrm{CaE}$ activity $(p<0.05)$. These inhibitions in the digestive gland $\mathrm{CaE}$ activity were approximately $20 \%$ in all exposure groups (Fig. 1). CaEs are an important group of serine hydrolases that hydrolyze many exogenous and endogenous compounds and play a significant role in the detoxification of agricultural chemicals. In particular, they act as an alternative receiver to prevent inhibition of $\mathrm{AChE}$ in organophosphate pesticide toxicity [2]. Similar to the results of the present study, Wu et al., reported that CaE activity was significantly inhibited in zebrafish exposed to imidacloprid at different concentrations [23]. 
A dose-related decrease in GR activity was observed in the digestive gland, but no significant change was observed in the gill. The lowest GR activity in the digestive gland was determined in the group exposed to $100 \mu \mathrm{g} \mathrm{AI} \mathrm{L}^{-1}$ with $30 \%$ inhibition compared to the control group $(p<0.05)$ (Fig. 1). It has been stated by Sobjak et al., that the inhibition of GR activity may be the result of a negative feedback cycle due to increase in GSH or the result of the presence of endogenous aldehydes resulting from lipid peroxidation [28]. Similarly, some researchers have reported that imidacloprid and other pesticides inhibit GR activity in different organisms [28, 29].

GST activity was significantly increased about $30 \%$ compared to the control group in the gill of mussels exposed to $1000 \mu \mathrm{g} \mathrm{AI} \mathrm{L}^{-1}$ imidacloprid ( $p<0.05$ ) (Fig. 1). However, no significant change in GST activity in the digestive glands was observed. GST protects cells from the deleterious effects of toxic end products of lipid peroxidation. Therefore, increased or unchanged GST activity is considered to be one of the mechanisms that prevent oxidative stress [30]. Similar to the results of this study, Wu et al., reported that imidacloprid induced GST activity in zebrafish embryos [23]. In another study, no significant changes in GST activity were observed in Cyprinus carpio larvae and juveniles exposed to thiacloprid, a neonicotinoid pesticide [31]. In addition, as reported by Vieira et al., [3], the increase in GST activity and GSH level at the highest exposure concentration reveals the activation of the antioxidant defense system.

The MDA level was induced at the highest exposure concentration in both tissues. The increase in the MDA level compared to the control group was approximately $45 \%$ in the digestive gland and $48 \%$ in the gill ( $p<0.05$ ), (Fig. 1). It is known that pesticides can affect the balance between the prooxidant and antioxidant system and the increased reactive oxygen species cause oxidative damage in lipids, proteins and nucleic acids [32]. Similar to the findings of this study, some researchers reported that imidacloprid induced MDA levels in various organisms. In a study on the effect of imidacloprid on the neotropical fish Prochilodus lineatus, it was observed that the MDA level in the fish brain was increased [3]. In addition, Köprücü et al., reported that MDA levels were significantly induced in the digestive glands and gills of freshwater mussels exposed to cypermethrin, a pyrethroid pesticide [33]. 

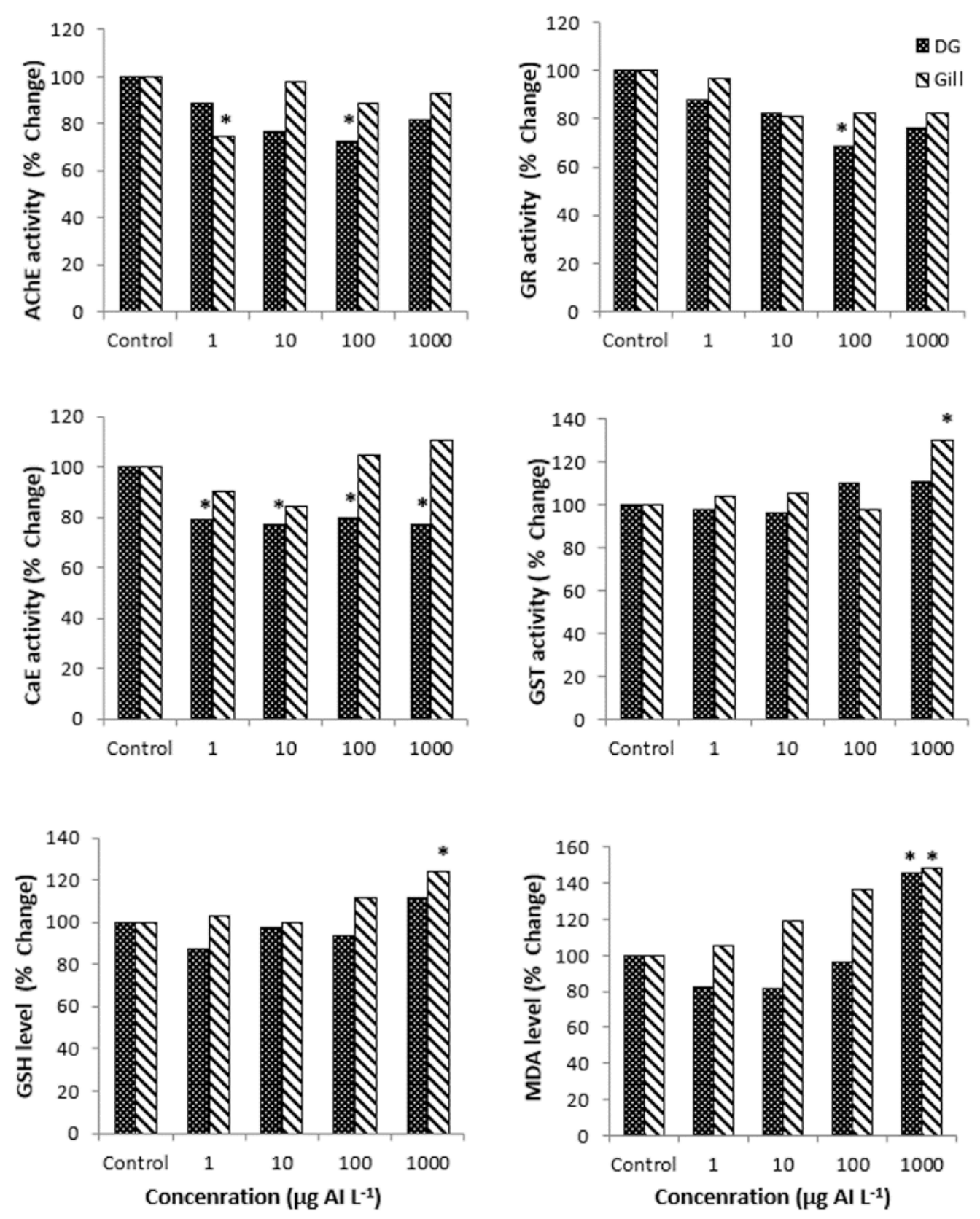

Figure 1 . The $\%$ changes of biochemical markers after exposure to different concentration of imidacloprid in digestive gland and gill of freshwater mussels. *: $p<0.05$ showed statistical importance compared with the control group 
Table 4. The biochemical response in digestive gland and gill of freshwater mussels after $96 \mathrm{~h}$ imidacloprid exposure (Enzyme activities expressed as nmol/min/mg

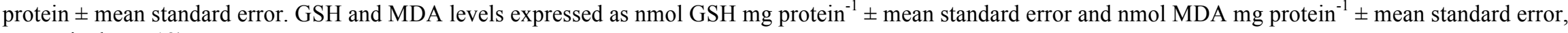
respectively. $\mathrm{n}=12$ )

\begin{tabular}{|c|c|c|c|c|c|c|c|c|c|c|c|c|c|c|c|c|c|c|c|}
\hline \multirow[t]{2}{*}{ Tissue } & \multirow{2}{*}{ 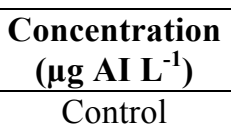 } & \multicolumn{3}{|c|}{ AChE } & \multicolumn{3}{|c|}{ GST } & \multicolumn{3}{|c|}{ GR } & \multicolumn{3}{|c|}{$\mathrm{CaE}$} & \multicolumn{3}{|c|}{ GSH } & \multicolumn{3}{|c|}{ MDA } \\
\hline & & 26.08 & \pm & 1.60 & 42.25 & \pm & 2.16 & 11.69 & \pm & 1.02 & 1048.01 & \pm & 51.50 & 70.33 & \pm & 1.45 & 0.75 & \pm & 0.07 \\
\hline \multirow{4}{*}{$\begin{array}{l}\text { Digestive } \\
\text { Gland }\end{array}$} & 1 & 23.79 & \pm & 1.10 & 41.22 & \pm & 1.31 & 10.26 & \pm & 1.13 & 827.70 & \pm & $32.33 *$ & 61.33 & \pm & 3.93 & 0.62 & \pm & 0.09 \\
\hline & 10 & 20.65 & \pm & 0.84 & 40.58 & \pm & 1.43 & 9.61 & \pm & 0.46 & 808.21 & \pm & $34.71 *$ & 68.67 & \pm & 8.18 & 0.61 & \pm & 0.05 \\
\hline & 100 & 19.46 & \pm & $1.72 *$ & 46.68 & \pm & 1.38 & 8.04 & \pm & $0.36 *$ & 837.76 & \pm & $40.47 *$ & 65.83 & \pm & 2.27 & 0.72 & \pm & 0.08 \\
\hline & 1000 & 21.93 & \pm & 0.85 & 46.34 & \pm & 1.15 & 8.88 & \pm & 0.31 & 805.15 & \pm & $34.89 *$ & 78.33 & \pm & 6.41 & 1.09 & \pm & $0.06 *$ \\
\hline \multirow{5}{*}{ Gill } & Control & 4.41 & \pm & 0.29 & 38.63 & \pm & 1.27 & 15.14 & \pm & 1.13 & 242.78 & \pm & 12.51 & 96.50 & \pm & 3.06 & 0.93 & \pm & 0.09 \\
\hline & 1 & 3.28 & \pm & $0.10 *$ & 40.16 & \pm & 3.09 & 14.60 & \pm & 1.02 & 219.23 & \pm & 13.54 & 99.33 & \pm & 3.55 & 0.98 & \pm & 0.06 \\
\hline & 10 & 4.30 & \pm & 0.17 & 40.69 & \pm & 1.22 & 12.27 & \pm & 1.33 & 204.68 & \pm & 7.68 & 96.33 & \pm & 6.47 & 1.11 & \pm & 0.06 \\
\hline & 100 & 3.92 & \pm & 0.47 & 37.96 & \pm & 2.31 & 12.41 & \pm & 0.99 & 254.12 & \pm & 15.32 & 107.83 & \pm & 4.84 & 1.27 & \pm & 0.05 \\
\hline & 1000 & 4.11 & \pm & 0.13 & 50.22 & \pm & $1.34 *$ & 12.48 & \pm & 0.65 & 267.91 & \pm & 8.91 & 119.67 & \pm & $4.22 *$ & 1.38 & \pm & $0.12 *$ \\
\hline
\end{tabular}

*: $p<0.05$ showed statistical importance compared with the control group 
The GSH levels in the gill were significantly induced at the highest exposure concentration with a $24 \%$ increase compared to the control group $(p<0.05)$ (Fig. 1). In the digestive gland, imidacloprid did not significantly affect the GSH level. GSH is a nonenzymatic intracellular antioxidant and serve as a cofactor of glutathione-dependent enzymes [34]. The increase in the GSH level is related to excessive pollution and protects the organisms against reactive oxygen radicals [35]. The increase in the gill GSH level is probably due to its improved synthesis, not from its low consumption. It can be considered as an indicator that GSH acts as a cofactor for GST which exhibits increased activity. Only a few studies in the literature on the effect of neonicotinoids on GSH levels in aquatic organisms support the data of this study. Velisek and Stara observed that the level of GSH did not change in the larvae and juveniles of common carps exposed to thiacloprid, a neonicotinoid pesticide [31]. In another study in which zebrafish was exposed to imidacloprid, it was determined that GSH level was induced in three tissues (brain, liver, and kidney) of zebrafish [36].

\section{Conclusion}

The data from this short-term laboratory study can provide various clues about the effects of imidacloprid on freshwater mussels that are exposed to sub-lethal concentrations. Considering all the analyzed biochemical markers, imidacloprid caused various changes in neurotoxicity, detoxification, and antioxidant defense responses. In conclusion, biochemical responses caused by imidacloprid toxicity in both tissues can be evaluated as early warning signals. In addition, the results showed that selected biochemical markers (especially AChE and MDA) are useful for freshwater mussels. However, more laboratory studies are needed to better understand the effects of shortterm imidacloprid toxicity on biochemical markers in freshwater mussels and this study will contribute to future studies.

\section{References}

[1] Arrighetti, F., Ambrosio, E., Astiz, M., Capítulo, A.R., Lavarías, S., Differential response between histological and biochemical biomarkers in the apple snail Pomacea canaliculata (Gasteropoda: Amullariidae) exposed to cypermethrin, Aquatic Toxicology, 194, 140-151, 2018. 
[2] Iummato, M.M., Sabatini, S.E., Cacciatore, L.C., Cochón, A.C., Cataldo, D., D., de Molina, M. D. C. R., Juárez, Á. B., Biochemical responses of the golden mussel Limnoperna fortunei under dietary glyphosate exposure, Ecotoxicology and Environmental Safety, 163, 69-75, 2018.

[3] Vieira, C.E.D., Pérez, M.R., Acayaba, R.D.A., Raimundo, C.C.M., dos Reis Martinez, C.B., DNA damage and oxidative stress induced by imidacloprid exposure in different tissues of the Neotropical fish Prochilodus lineatus, Chemosphere, 195, 125$134,2018$.

[4] Prosser, R.S., De Solla, S.R., Holman, E.A.M., Osborne, R., Robinson, S.A., Bartlett, A.J., Maisonneuve, F.J., Gillis, P.L., Sensitivity of the early-life stages of freshwater mollusks to neonicotinoid and butenolide insecticides, Environmental Pollution, 218, 428-435, 2016.

[5] Vehovszky, Á., Farkas, A., Csikós, V., Székács, A., Mörtl, M., Győri, J., Neonicotinoid insecticides are potential substrates of the multixenobiotic resistance (MXR) mechanism in the non-target invertebrate, Dreissena sp, Aquatic Toxicology, 205, 148-155, 2018.

[6] Miranda, G.R., Raetano, C.G., Silva, E., Daam, M.A., Cerejeira, M.J., Environmental fate of neonicotinoids and classification of their potential risks to hypogean, epygean, and surface water ecosystems in Brazil, Human and Ecological Risk Assessment, An International Journal, 17(4), 981-995, 2011.

[7] Hanana, H., Turcotte, P., André, C., Gagnon, C., Gagné, F., Comparative study of the effects of gadolinium chloride and gadolinium-based magnetic resonance imaging contrast agent on freshwater mussel, Dreissena polymorpha, Chemosphere, 181, 197207, 2017.

[8] Güngördü, A., Comparative toxicity of methidathion and glyphosate on early life stages of three amphibian species: Pelophylax ridibundus, Pseudepidalea viridis, and Xenopus laevis, Aquatic Toxicology, 140, 220-228, 2013.

[9] Solé, M., Bonsignore, M., Rivera-Ingraham, G., Freitas, R., Exploring alternative biomarkers of pesticide pollution in clams, Marine Pollution Bulletin, 136, 61-67, 2018.

[10] Pereira, P., Pablo, H., Vale, C., Pacheco, M., Combined use of environmental data and biomarkers in fish (Liza aurata) inhabiting a eutrophic and metal-contaminated coastal system-Gills reflect environmental contamination, Marine Environmental Research, 69, 53-62, 2010.

[11] Yang, X., Song, Y., Kai, J., Cao, X., Enzymatic biomarkers of earthworms Eisenia fetida in response to individual and combined cadmium and pyrene, Ecotoxicology and Environmental Safety, 86, 162-167, 2012. 
[12] Khazri, A., Sellami, B., Hanachi, A., Dellali, M., Eljarrat, E., Beyrem, H., Mahmoudi, E., Neurotoxicity and oxidative stress induced by permethrin in gills of the freshwater mussel Unio ravoisieri, Chemistry and Ecology, 33(1), 88-101, 2017.

[13] Çekiç, F.Ö., Ekinci, S., İnal, M.S., Ünal, D., Silver nanoparticles induced genotoxicity and oxidative stress in tomato plants, Turkish Journal of Biology, 41(5), 700-707, 2017.

[14] USEPA, Aquatic Life Benchmarks and Ecological Risk Assessments for Registered Pesticides; OPP Aquatic Life Benchmarks, 2017, Link: https://www.epa.gov/pesticide-science-and-assessing-pesticide-risks/aquatic-life benchmarks-and-ecological-risk\#benchmarks [accessed 10 April 2019].

[15] Bradford, M., A rapid and sensitive method for the quantitation of microgram quantities of protein utilizing the principle of protein-dye binding, Analytical Biochemistry, 72, 248-254, 1976.

[16] Jollow, D.J., Mitchell, J.R., Zampaglione, N.A., Gillette, J.R., Bromobenzeneinduced liver necrosis. Protective role of glutathione and evidence for 3, 4-bromobenzene oxide as the hepatotoxic metabolite, Pharmacology, 11(3), 151-169, 1974.

[17] Ohkawa, H., Ohishi, N., Yagi, K., Assay for lipid peroxides in animal tissues by thiobarbituric acid reaction, Analytical Biochemistry, 95(2), 351-358, 1979.

[18] Habig, W.H., Pabst, M.J., Jacoby, W.B., Glutathione S-transferases. The first enzymatic step in mercapturic acid formation, Journal of Biological Chemistry, 249, 7130-7139, 1974.

[19] Santhoshkumar, P., Shivanandappa, T., In vitro sequestration of two organophosphorus homologs by the rat liver, Chemico-Biological Interactions, 119- 120, 277-282, 1999.

[20] Elman, G.L., Courtney, K.D., Andres, J.V., Featherstone, R.M., New and rapid colorimetric determination of acetylcholinesterase activity, Biochemical Pharmacology, 7, 88-95, 1961.

[21] Cribb, A., Leeder, J., Spielberg, S.P., Use of a microplate reader in an assay of glutathione reductase using 5,5'-dithiobis(2-nitrobenzoic acid), Analytical Biochemistry, 183, 195-196, 1989.

[22] Korkmaz, V., Güngördü, A., Ozmen, M., Comparative evaluation of toxicological effects and recovery patterns in zebrafish (Danio rerio) after exposure to phosalone-based and cypermethrin-based pesticides, Ecotoxicology and Environmental Safety, 160, 265-272, 2018.

[23] Wu, S., Li, X., Liu, X., Yang, G., An, X., Wang, Q., Wang, Y., Joint toxic effects of triazophos and imidacloprid on zebra fish (Danio rerio), Environmental Pollution, 235, 470-481, 2018. 
[24] Qi, S., Wang, D., Zhu, L., Teng, M., Wang, C., Xue, X., Wu, L., Neonicotinoid insecticides imidacloprid, guadipyr, and cycloxaprid induce acute oxidative stress in Daphnia magna, Ecotoxicology and Environmental Safety, 148, 352-358, 2018.

[25] Dondero, F., Negri, A., Boatti, L., Marsano, F., Mignone, F., Viarengo, A., Transcriptomic and proteomic effects of a neonicotinoid insecticide mixture in the marine mussel (Mytilus galloprovincialis, Lam.), Science of the Total Environment, 408(18), 3775-3786, 2010.

[26] Azevedo-Pereira, H.M.V.S., Lemos, M.F.L., Soares, A.M., Effects of imidacloprid exposure on Chironomus riparius Meigen larvae: linking acetylcholinesterase activity to behaviour, Ecotoxicology and Environmental Safety, 74(5), 1210-1215, 2011.

[27] Jemec, A., Tišler, T., Drobne, D., Sepčić, K., Fournier, D., Trebše, P., Comparative toxicity of imidacloprid, of its commercial liquid formulation and of diazinon to a non-target arthropod, the microcrustacean Daphnia magna, Chemosphere, 68(8), 1408-1418, 2007.

[28] Sobjak, T.M., Romão, S., Cazarolli, L.H., Sampaio, S.C., Remor, M.B., Guimarães, A.T.B., Evaluation of the antioxidant system and neurotoxic effects observed in Rhamdia branneri (Teleostei: Heptapteridae) sampled from streams of the lower Iguazu River basin, Ecotoxicology and Environmental Safety, 155, 162-170, 2018.

[29] Mahajan, L., Verma, P.K., Raina, R., Pankaj, N.K., Sood, S., Singh, M., Alteration in thiols homeostasis, protein and lipid peroxidation in renal tissue following subacute oral exposure of imidacloprid and arsenic in Wistar rats, Toxicology Reports, 5, 1114-1119, 2018.

[30] Iturburu, F.G., Zömisch, M., Panzeri, A.M., Crupkin, A.C., Contardo-Jara, V., Pflugmacher, S., Menone, M.L., Uptake, distribution in different tissues, and genotoxicity of imidacloprid in the freshwater fish Australoheros facetus, Environmental Toxicology and Chemistry, 36(3), 699-708, 2017.

[31] Velisek, J., Stara, A., Effect of thiacloprid on early life stages of common carp (Cyprinus carpio), Chemosphere, 194, 481-487, 2018.

[32] Topal, A., Alak, G., Ozkaraca, M., Yeltekin, A.C., Comakl1, S., Ac1l, G., Kokturk, M., Atamanalp, M., Neurotoxic responses in brain tissues of rainbow trout exposed to imidacloprid pesticide: assessment of 8-hydroxy-2-deoxyguanosine activity, oxidative stress and acetylcholinesterase activity, Chemosphere, 175, 186-191, 2017.

[33] Köprücü, K., Yonar, S.M., Şeker, E., Effects of cypermethrin on antioxidant status, oxidative stress biomarkers, behavior, and mortality in the freshwater mussel Unio elongatulus eucirrus, Fisheries Science, 76(6), 1007-1013, 2010.

[34] Lunardelli, B., Cabral, M.T., Vieira, C.E., Oliveira, L.F., Risso, W.E., Meletti, P.C., Martinez, C.B., Chromium accumulation and biomarker responses in the 
Neotropical fish Prochilodus lineatus caged in a river under the influence of tannery activities, Ecotoxicology and Environmental Safety, 153, 188-194, 2018.

[35] Faria, M., Soares, A.M., Caiola, N., Barata, C., Effects of Camellia sinensis crude saponin on survival and biochemical markers of oxidative stress and multixenobiotic resistance of the Mediterranean mussel, Mytilus galloprovincialis, Science of the Total Environment, 625, 1467-1475, 2018.

[36] Shukla, S., Jhamtani, R.C., Dahiya, M.S., Agarwal, R., Oxidative injury caused by individual and combined exposure of neonicotinoid, organophosphate and herbicide in zebrafish, Toxicology Reports, 4, 240-244, 2017. 